\title{
Production and Evaluation of Gluten Free Balady Bread
}

\author{
${ }^{1}$ Mostafa S.M.T.M., ${ }^{2}$ Rizk I.R.S., ${ }^{2}$ Kishk Y.F.M. and ${ }^{1}$ Siham M.M. Faheid
}

\author{
${ }^{1}$ Food Tech. Dept., Food Industry and Nutrition Research Division, National Research Centre, 33 El \\ Buhouth St., 12622 Dokki, Giza, Egypt. \\ ${ }^{2}$ Food Sci. Dept., Fac. of Agric., Ain Shams Univ., 68 Hadayek Shoubra P.O. Box 11241, Cairo, \\ Egypt.
}

Received: 25 March 2020 / Accepted 20 May 2020 / Publication date: 15 June 2020

\begin{abstract}
From the point of an increasing demand for improvement the quality of gluten-free Balady bread (GFBB), the objective of this study was to investigate this demand by using gluten free mixture, i.e. white corn flour (WCF), rice flour (RF) and potato starch (PS) at different ratios Also, soy protein isolate (SPI) was used as a rich source of protein. Psyllium husk (PsH) and carboxymethyl cellulose $(\mathrm{CMC})$ were used as binding agents as a trials to reach the specifications of the quality of wheat Balady bread. The proportional of WCF, RF, PS and SPI were optimized for production of GFBB with $2.5 \%$ PsH or $2.5 \%$ CMC. Physic-chemical, staling, and sensory properties of GFBB bread formulation were estimated. Results show that the protein content of GFBB was gradually decreased with the increasing level of PS, where the GFBB which produced from $45 \% \mathrm{WCF}+45 \% \mathrm{RF}+10 \%$ SPI and $37.5 \% \mathrm{WCF}+37.5 \% \mathrm{RF}+15 \% \mathrm{PS}=10 \% \mathrm{SPI}$ significantly $(P \geq 0.05)$ recorded the higher value of protein and the lower value of nitrogen free extract (NFE) compared to WF (control). The highest value of lightness ( $\mathrm{L}^{*}$ value) for crust color was observed by the sample produced from $100 \%$ WCF. The psyllium husk showed high quality properties compared to CMC concerning physical and sensory characteristics, where no significant difference could be observed between the GFBB containing $2.5 \%$ $\mathrm{PsH}$ and the Balady bread prepared from 100\% WF (82\% ext.) in terms of specific volume of bread, whereas the GFBB samples containing $2.5 \%$ CMC showed lower quality attributes which gradually improved with increasing level of PS. Also, the samples containing PsH were more resistance to staling compared the others which containing CMC. On the other side, the more of GFBB containing $\mathrm{PsH}$ showed higher values of sensory parameters with no significant differences compared to the Balady bread produced from $100 \%$ WF especially for crust color, separation of layers, texture, taste and overall acceptability.
\end{abstract}

Keywords: Carboxymethyl cellulose, celiac, gluten-free bread, potato starch, psyllium husk, white corn flour

\section{Introduction}

Celiac disease (CD) is a disorder identified as permanent intolerance to gluten, more specifically to the prolamin fraction of wheat (gliadin), rye (secalin) and barley (hordein) (Dizlek and Ozer, 2016). The wheat gluten consists of gliadin and glutenin fractions which have high proline content in amino acid sequences and glutamine residues. High glutamine and proline content makes gluten proteins resistant to gastrointestinal digestion enzymes. After reaching the gluten to small intestine, gluten activates immune response and the mucosa structure is damaged then causes malabsorption and the problems related with it (Kömen, 2010).

Bread is considered a staple food worldwide. In Egypt the public bread is Balady bread, meanwhile it is the main staple in the Middel Eastern diet. Balady bread production is supported by the Egyptian government and produced from wheat flour contained 10 to $12 \%$ protein and described as round flat bread (15-20 cm diameter) and weight $60-65 \mathrm{~g}$ (Mousa et al., 1979).

In spite of availability of gluten-free products the nutritional quality of gluten-free products still remains a critical issue. Since low levels of protein, fiber, and essential nutrients (Conte et al., 2019). However, nutritional value of the gluten-free products is important challenging because of the increasing segment of population with celiac disease (Aprodu et al., 2016). The addition of the protein products to different food matrices is mainly decided based on the specific functional properties, such

Corresponding Author: Mostafa S.M.T.M., Food Tech. Dept., Food Industry and Nutrition Research Division, National Research Centre, 33 El Buhouth St., 12622 Dokki, Giza, Egypt. E-mail: abnody.sayed@gmail.com 
as water-binding and holding capacities (Marco and Rosell 2008a). Such as soy addition will reduce the stretching or pouting capacity of the wholegrain rice flour-based batters and doughs, this combination being more suitable for obtaining spreadable gluten-free formulations (Pătraşcu et al., 2017). Moreover, soy proteins are usually added into the bread formula either as soy protein isolates or high-protein soy flour to improve mechanical behavior of dough, as well as textural properties, specific volume, and nutritional value of gluten-free bread (Marco and Rosell, 2008b).

Psyllium fiber generally enhanced the physical properties of the doughs, due to the film-like structure that it was able to form, and the most complex among the experimental formulations looked promising in terms of final bread technological and nutritional quality (Mariotti et al., 2009). Also, the addition of psyllium husk to wheat flour affects the rheological characteristics in various ways and significantly increase of water absorption. On the other hand, CMC is used for maintaining moisture, improvement the mouth-feel and structural consistency of bakery products (Kohajdová and Karovičová 2009).

Generally, gluten-free bakery products especially breads often have poor crust and crumb characteristics and very fast staling, and the current study was conducted to help alleviate this problem, and the aim of this work was to improve the quality of gluten-free Balady bread.

\section{Materials and Methods}

\section{Materials}

Wheat flours ( $82 \%$ ex.) were obtained from North Cairo Flour Mills Company, Egypt. White corn flour, rice flour were purchased from the local market (Giza, Egypt). Potato starch (Emsland Group, Germany). Soy protein isolate (SPI) was obtained from American Food Chem, Carboxymethyl cellulose (CMC) was obtained from Sigma CO. Psyllium husk (Plantago psyllium) manufactured by NOW FOOD 395 S. Glen Ellyn Rd. USA.

All Other ingredients, Instant active dry yeast (ADY) (Saccharomyces cerevisiae) and salt, obtained from the local market, Cairo, Egypt. All chemicals used in the estimation and analysis in this study were analytical grade.

\section{Analytical methods}

\section{Chemical composition}

Moisture content, crude protein, lipids, ash and crude fiber contents were determined according to A.O.A.C. (2000). Nitrogen free extract (NFE) was calculated by differences.

\section{Preparation of composite flour}

Wheat flour ( $82 \%$ ext.) was used at percent $100 \%$ to produce wheat Balady bread, also white corn flour was used at the percent $100 \%$ to produce white corn Balady bread. While the other glutenfree formulas consist from $10 \%$ soy protein isolate and $2.5 \%$ psyllium husk or $2.5 \%$ CMC with different level of WCF, RF and PS as presented in Table 1. The flour mixtures were individually, blended homogenized then packed in polyethylene bags which tightly closed and stored at $-18^{\circ} \mathrm{C}$ until used.

Table 1: Balady bread formulas

\begin{tabular}{|c|c|c|c|c|c|c|c|}
\hline \multirow{2}{*}{ Samples } & \multicolumn{7}{|c|}{ Raw materials } \\
\hline & WF & WCF & RF & PS & SPI & PsH & CMC \\
\hline Control 1 & 100.00 & -- & -- & -- & -- & -- & -- \\
\hline Control 2 & -- & 100.00 & -- & -- & -- & -- & -- \\
\hline A & -- & 45.00 & 45.00 & -- & 10.00 & 2.50 & -- \\
\hline B & -- & 37.50 & 37.50 & 15.00 & 10.00 & 2.50 & -- \\
\hline $\mathrm{C}$ & -- & 30.00 & 30.00 & 30.00 & 10.00 & 2.50 & -- \\
\hline D & -- & 22.50 & 22.50 & 45.00 & 10.00 & 2.50 & -- \\
\hline $\mathbf{E}$ & -- & 15.00 & 15.00 & 60.00 & 10.00 & 2.50 & -- \\
\hline F & -- & 45.00 & 45.00 & -- & 10.00 & -- & 2.50 \\
\hline $\mathbf{G}$ & -- & 37.50 & 37.50 & 15.00 & 10.00 & -- & 2.50 \\
\hline $\mathbf{H}$ & -- & 30.00 & 30.00 & 30.00 & 10.00 & -- & 2.50 \\
\hline I & -- & 22.50 & 22.50 & 45.00 & 10.00 & -- & 2.50 \\
\hline $\mathbf{J}$ & -- & 15.00 & 15.00 & 60.00 & 10.00 & -- & 2.50 \\
\hline
\end{tabular}

Where: $\mathbf{W F}=$ Wheat flour, $\mathbf{W C F}=$ White corn flour, $\mathbf{R F}=$ Rice flour, $\mathbf{P S}=$ Potato starch, $\mathbf{S P I}=$ Soy protein isolate, $\mathbf{P s H}=$ Psyllium Husk and $\mathbf{C M C}=$ Carboxymethyl cellulose 


\section{Balady bread making process}

Balady bread was prepared according to the method described by Faridi, and Rubenthaler (1984). Bread making involved mixing $100 \mathrm{~g}$ wheat flour ( $82 \%$ extraction), salt $(1.5 \% \mathrm{w} / \mathrm{w})$, active dry yeast (ADY) $(1 \% \mathrm{w} / \mathrm{w})$ and water as need. Ingredients were mixed until the dough was developed, then the resulted dough was let to rest for $10 \mathrm{~min}$ then divided. The pieces of dough were placed on a try sprinkled with a thin layer of wheat bran and let to ferment for 40 min. at $30 \pm 2^{\circ} \mathrm{C}$ and $85 \%$ relative humidity (final proofing). The pieces were then flattened to about $15 \mathrm{~cm}$ diameters and baked directly at $450-500^{\circ} \mathrm{C}$ for $1-2 \mathrm{~min}$ in a pilot plant oven (Food Technology Dep. National Research Center (NRC), Giza, Egypt). After baking, loaves were allowed to cool at room temperature before sealed in polyethylene bags to prevent moisture loss then storage at room temperature $\left(18 \pm 2^{\circ} \mathrm{C}\right)$.

\section{Color determination of Balady bread}

Color of Egyptian bread untreated and treated was measured using spectro-colourimeter (Tristimulus Color Machine) with the CIE lab color scale (International Commission on Illumination) as mentioned by Hunter, (1958). Color of untreated and treated Egyptian bread samples was measured using a Hunter Lab colorimeter Hunter $a^{*}, b^{*}$ and $L^{*}$ parameters were measured with a color difference meter using a spectro-colorimeter (Tristimulus Color Machine) with the CIE lab color scale (Hunter, Lab Scan XE - Reston VA, USA) in the reflection mode. The instrument was standardized each time with white tile of Hunter Lab Color Standard (LX No.16379): $X=72.26, Y=81.94$ and $Z=$ $88.14\left(\mathrm{~L}^{*}=92.46 ; \mathrm{a}^{*}=-0.86 ; \mathrm{b}^{*}=-0.16\right)$. The instrument $\left(65^{\circ} / 0^{\circ}\right.$ geometry, D25 optical sensor, $10^{\circ}$ observer) was calibrated using white and black reference tiles. The colour values were expressed as $\mathrm{L}^{*}$ (lightness or brightness/ darkness), $\mathrm{a} *$ (redness/greenness) and b* (yellowness/blueness).

\section{Physical properties of Balady bread}

Loaf volume $\left(\mathrm{cm}^{3}\right)$ was determined by measurement of rapeseed displacement after the bread had been dried at room temperature for one day to harden its surface, specific volume $\left(\mathrm{cm}^{3} / \mathrm{g}\right)$ was calculated by dividing the volume by the weight (g) according to A.A.C.C. (2000).

\section{Alkaline water retention capacity of bread}

Balady bread loaves freshness was tested after wrapping using polyethylene bags and storage at room temperature (1,2 and 3 days) using Alkaline Water Retention Capacity test (AWRC) according to the method of Yamazaki (1954), as modified by Kitterman and Rubanthaler (1971).

AWRC $(\%)=[($ Weight of tube with sample after centrifuge - weight of empty tube $) /$ Weight of sample] x 100.

\section{Sensory characteristics}

Sensory evaluation of Balady bread was evaluated by 10 panelists according to Abdelghafor et al., (2011) with some modification. by using a 10 points scales; crust color $(1=$ dull brown/whitish and $10=$ golden brown), Separation of layer $(1=$ not separated and $10=$ separated two layer and inflate), Roundness $(1=$ no specific form and $10=$ round $)$, texture $(1=$ hard $/$ putty and $10=$ normal $)$, crumb color $(1=$ brown and $10=$ creamish white), distribution of crumb $(1=$ irregular and $10=$ uniform), taste $(1=$ off flavor, off taste and $10=$ normal $)$, odor $(1=$ undesirable and $10=$ fermented and natural $)$ and mouth feel $(1=$ doughy/gritty and $10=$ clean mouth feel/no residue).

\section{Statistical analysis}

The obtained results were statistically analyzed by using SPSS computer software (SPSS, 2000). The statistical was performed by analysis of variance (ANOVA) and significant differences among Duncan's multiple test at $(P \leq 0.05)$ according to Waller and Duncan (1969).

\section{Results and Discussion}

\section{Proximate chemical composition of raw materials}

According to the obtained results presented in Table 2. it could be noticed that, the lowest value of moisture content $(7.11 \%)$ was observed by the soy protein isolate (SPI) with significant difference $(P<0.05)$, followed by $8.96 \%$ which recorded by rice flour, while, the highest value of moisture content $(14.25 \%)$ was observed by the wheat flour ( $82 \%$ ex.). Concerning to the protein content, soy 
protein isolate recorded the highest value $(87.74 \%)$, in contrary to the potato starch which recorded the lowest value of protein content $(0.16 \%)$. Also potato starch recorded the lowest values of crude lipids, ash and crude fiber contents $(0.17,0.03$ and $0.01 \%$ respectively) with significant differences on contrast to the highest value $(99.63 \%)$ of nitrogen free extract (NFE) which recorded by potato starch compared to the lowest value of NFE (8.67\%) which recorded by SPI with significant difference.

Table 2: Proximate chemical composition of wheat flour ( $82 \%$ ext.), white corn flour, rice flour, soy protein isolate and potato starch (\% on dry weight bases).

\begin{tabular}{lcccccc}
\hline Samples & Moisture & Protein & Crud lipid & Ash & Crude fiber & NFE \\
\hline Wheat flour (82\% ext.) & $14.25^{\mathrm{a}}$ & $13.64^{\mathrm{b}}$ & $1.59^{\mathrm{b}}$ & $0.85^{\mathrm{c}}$ & $1.48^{\mathrm{b}}$ & $82.44^{\mathrm{c}}$ \\
White corn flour & $9.33^{\mathrm{c}}$ & $9.76^{\mathrm{c}}$ & $4.24^{\mathrm{a}}$ & $1.27^{\mathrm{b}}$ & $2.94^{\mathrm{a}}$ & $81.79^{\mathrm{c}}$ \\
Rice flour & $8.96^{\mathrm{d}}$ & $7.16^{\mathrm{d}}$ & $1.50^{\mathrm{c}}$ & $0.57^{\mathrm{c}}$ & $1.21^{\mathrm{c}}$ & $89.56^{\mathrm{b}}$ \\
Soy protein isolate & $7.11^{\mathrm{e}}$ & $87.74^{\mathrm{a}}$ & $0.43^{\mathrm{d}}$ & $2.87^{\mathrm{a}}$ & $0.29^{\mathrm{d}}$ & $8.67^{\mathrm{d}}$ \\
Potato starch & $13.19^{\mathrm{b}}$ & $0.16^{\mathrm{e}}$ & $0.17^{\mathrm{e}}$ & $0.03^{\mathrm{d}}$ & $0.01^{\mathrm{e}}$ & $99.63^{\mathrm{a}}$ \\
\hline
\end{tabular}

Means in the same column with different letters are significantly different $(P<0.05)$.

*NFE $=$ Nitrogen free extract calculated by difference.

However, white corn flour (WCF) recorded the highest values of crude lipids and crude fiber (4.24 and $2.94 \%$ respectively) with significant differences. These results were in agreement with those Amir et al., (2015) they studied the chemical composition of wheat flour and found its contained $13.90 \%$ protein, $1.73 \%$ crude fiber, $1.28 \%$ ash and $1.50 \%$ fat content.

Proximate chemical composition of wheat Balady bread and gluten-free Balady bread prepared by using different flours blends with $2.5 \%$ psyllium husk or $2.5 \%$ CMC.

The approximate chemical composition of wheat Balady bread and gluten-free Balady bread were presented in Table 3. The results showed that, the lowest values of moisture content in Balady bread samples were observed by the samples produced from $100 \%$ wheat flour $(31.04 \%)$ with significant differences also, the Balady bread sample produced from 100\% WCF recorded lower value of moisture content.

Table 3: Proximate chemical composition of wheat Balady bread and gluten-free Balady bread prepared.

\begin{tabular}{ccccccc}
\hline Balady bread samples & Moisture & Protein & Lipids & Ash & Crude fiber & NFE \\
\hline WF (control) & $31.04^{\mathrm{h}}$ & $16.24^{\mathrm{b}}$ & $1.74^{\mathrm{e}}$ & $1.16^{\mathrm{l}}$ & $1.64^{\mathrm{e}}$ & $79.22^{\mathrm{e}}$ \\
WCF & $32.06^{\mathrm{g}}$ & $11.71^{\mathrm{f}}$ & $4.46^{\mathrm{a}}$ & $1.88^{\mathrm{a}}$ & $3.10^{\mathrm{a}}$ & $78.85^{\mathrm{f}}$ \\
\hline GFMF with $\mathbf{2 . 5 \%}$ PsH & & & & & & \\
A & $33.16^{\mathrm{f}}$ & $18.22^{\mathrm{a}}$ & $2.46^{\mathrm{b}}$ & $1.72^{\mathrm{b}}$ & $2.02^{\mathrm{b}}$ & $75.58^{\mathrm{h}}$ \\
B & $34.23^{\mathrm{de}}$ & $16.72^{\mathrm{b}}$ & $2.13^{\mathrm{c}}$ & $1.58^{\mathrm{d}}$ & $1.78^{\mathrm{d}}$ & $77.79^{\mathrm{g}}$ \\
$\mathbf{C}$ & $35.30^{\mathrm{ab}}$ & $15.89^{\mathrm{c}}$ & $1.81^{\mathrm{d}}$ & $1.47^{\mathrm{f}}$ & $1.73^{\mathrm{d}}$ & $79.01^{\mathrm{e}}$ \\
$\mathbf{D}$ & $35.77^{\mathrm{ab}}$ & $14.40^{\mathrm{d}}$ & $1.68^{\mathrm{f}}$ & $1.33^{\mathrm{h}}$ & $1.43^{\mathrm{f}}$ & $81.16^{\mathrm{cd}}$ \\
E & $35.97^{\mathrm{a}}$ & $13.43^{\mathrm{e}}$ & $1.47^{\mathrm{g}}$ & $1.21^{\mathrm{j}}$ & $1.11^{\mathrm{h}}$ & $82.78^{\mathrm{b}}$ \\
\hline GFMF with $\mathbf{2 . 5 \% ~ C M C}$ & & & & & & \\
F & $32.11^{\mathrm{g}}$ & $18.19^{\mathrm{a}}$ & $2.45^{\mathrm{b}}$ & $1.64^{\mathrm{c}}$ & $1.95^{\mathrm{c}}$ & $75.77^{\mathrm{h}}$ \\
$\mathbf{G}$ & $33.30^{\mathrm{f}}$ & $16.76^{\mathrm{b}}$ & $2.13^{\mathrm{c}}$ & $1.51^{\mathrm{e}}$ & $1.63^{\mathrm{e}}$ & $77.77^{\mathrm{g}}$ \\
$\mathbf{H}$ & $33.58^{\mathrm{ef}}$ & $16.05^{\mathrm{c}}$ & $1.80^{\mathrm{d}}$ & $1.40^{\mathrm{g}}$ & $1.32^{\mathrm{g}}$ & $79.43^{\mathrm{d}}$ \\
$\mathbf{I}$ & $34.71^{\mathrm{cd}}$ & $14.65^{\mathrm{d}}$ & $1.66^{\mathrm{f}}$ & $1.27^{\mathrm{i}}$ & $0.99^{\mathrm{i}}$ & $81.43^{\mathrm{c}}$ \\
$\mathbf{J}$ & $34.92^{\mathrm{bc}}$ & $13.52^{\mathrm{e}}$ & $1.47^{\mathrm{g}}$ & $1.13^{\mathrm{m}}$ & $0.69^{\mathrm{j}}$ & $83.19^{\mathrm{a}}$ \\
\hline
\end{tabular}

Means in the same column with different letters are significantly different $(\mathrm{P}<0.05)$.

$\mathbf{N F E}=$ Nitrogen free extract calculated by difference

$\mathbf{G F M F}=$ Gluten free mixture flour

$\mathbf{W F}=$ Wheat flour $(82 \%$ ext. $)$

$\mathbf{W C F}=$ White corn flour

A and $\mathbf{F}=45 \%$ white corn flour $+45 \%$ rice flour $+10 \%$ soy protein isolate

B and $\mathbf{G}=37.5 \%$ white corn flour $+37.50 \%$ rice flour $+15 \%$ potato starch $+10 \%$ soy protein isolate

$\mathbf{C}$ and $\mathbf{H}=30 \%$ white corn flour $+30 \%$ rice flour $+30 \%$ potato starch $+10 \%$ soy protein isolate

D and $\mathbf{I}=22.5 \%$ white corn flour $+22.50 \%$ rice flour $+45 \%$ potato starch $+10 \%$ soy protein isolate

$\mathbf{E}$ and $\mathbf{J}=15 \%$ white corn flour $+15 \%$ rice flour $+60 \%$ potato starch $+10 \%$ soy protein isolate 
However all the GFBB samples containing PsH or CMC were gradually increased moisture content, with the increment of PS, probably due to the ability of starch to hold water in the produced bread as reported by Eke-Ejiofor and Owuno (2014). While when comparing between the GFBB samples containing PsH with others containing CMC the results indicated that PsH had more effect concerning the moisture contents of breads where, the highest value of moisture content was obtained by the sample contained $60 \%$ PS with $2.5 \%$ PsH (sample E) with significant compared to all samples contained CMC. Also, the GFBB contained PsH showed higher values in terms of the fiber contents compared to the GFBB samples which contained CMC

Thus, the highest value of protein content were obtained in GFBB samples A,B,F and $G$ compared to WF bread. As for the protein and lipids contents no significant differences between all GFBB samples contained PsH or CMC. Whilst, the highest value of crude fiber significantly was recorded by the sample produced from $100 \%$ WCF. In generally the incorporation of protein isolates and fiber in gluten-free bread making contribute to enhanced nutritional value (improve protein i.e. fiber content) as reported by Felisberto et al., (2015).

\section{Color attributes of wheat Balady bread and gluten-free Balady bread.}

From the results in Table 4 it could be noticed that concerning the lightness (high $\mathrm{L}^{*}$ value) of crust color, the Balady bread samples which produced from 100\% WCF was more lightness (68.62) with no significant difference compared to the GFBB samples A, B and F. However all GFBB samples were gradually decreased with the increment of the PS rate in terms of the L* value (more darkness) and explained by Boyacioglu and D'appolonia (1994) as the dark coloration of bread is influenced by the rise of the rate of both damaged starch and total sugars present in flour, which were highest in starch potato. Meanwhile, the GFBB samples containing $2.5 \%$ CMC were more darker crust than others containing $2.5 \% \mathrm{PsH}$. In generally, the darkness due to Maillard browning and caramelization which are influenced by the distribution of water and the reaction of reducing sugars and amino acids (Kent and Evers, 1994).

Also, the variation in starch content may be referred to the variation in enzyme activities of different Saccharomyces cerevisiae strains which degrade starch into more fermentable sugars (Heitmann et al., 2015). On the other hand, the redness and yellowness of all GFBB samples were in inverse proportion to the potato starch and this was in agreement with Raymundo et al. (2014) they reported that the darkening of produced products due to the inclusion of fiber and when increasing psyllium husk, the $L^{*}$ value increased while the $b^{*}$ and $a^{*}$ values decreased.

Table 4: Color attributes of wheat Balady bread and gluten-free Balady bread prepared by using different flours blends with $2.5 \%$ psyllium husk or $2.5 \%$ carboxymethyl cellulose.

\begin{tabular}{cccc}
\hline \multirow{2}{*}{ Balady bread samples } & \multicolumn{3}{c}{ Crust color parameters } \\
\cline { 2 - 4 } WF (control) & L & a & b \\
WCF & $61.64^{\mathrm{cd}}$ & $11.39^{\mathrm{a}}$ & $25.65^{\mathrm{de}}$ \\
\hline GFMF with 2.5\% PsH & $68.62^{\mathrm{a}}$ & $8.26^{\mathrm{d}}$ & $28.70^{\mathrm{b}}$ \\
A & & & \\
B & $68.56^{\mathrm{a}}$ & $7.38^{\mathrm{de}}$ & $32.62^{\mathrm{a}}$ \\
C & $67.68^{\mathrm{a}}$ & $7.56^{\mathrm{de}}$ & $29.19^{\mathrm{b}}$ \\
D & $63.64^{\mathrm{bc}}$ & $7.77^{\mathrm{de}}$ & $26.14^{\mathrm{d}}$ \\
$\mathbf{E}$ & $62.80^{\mathrm{bc}}$ & $8.27^{\mathrm{d}}$ & $26.13^{\mathrm{cd}}$ \\
\hline GFMF with 2.5\% CMC & $60.24^{\mathrm{d}}$ & $10.83^{\mathrm{b}}$ & $25.95^{\mathrm{cd}}$ \\
F & & & \\
G & $68.18^{\mathrm{a}}$ & $6.90^{\mathrm{e}}$ & $29.51^{\mathrm{b}}$ \\
$\mathbf{H}$ & $64.26^{\mathrm{b}}$ & $8.22^{\mathrm{d}}$ & $27.31^{\mathrm{c}}$ \\
I & $56.12^{\mathrm{e}}$ & $9.64^{\mathrm{c}}$ & $25.32^{\mathrm{de}}$ \\
J & $54.31^{\mathrm{ef}}$ & $10.58^{\mathrm{bc}}$ & $24.94^{\mathrm{de}}$ \\
\hline
\end{tabular}

Means in the same column with different letters are significantly different $(\mathrm{P}<0.05)$.

$\mathbf{W F}=$ Wheat flour $(82 \%$ ext. $)$

$\mathbf{W C F}=$ White corn flour.

$\mathbf{G F M F}=$ Gluten free mixture flour. 


\section{Physical properties of wheat Balady bread and gluten-free Balady bread}

Quality attributes of Balady bread (weight, volume and specific volume) produced from $100 \%$ WF ( $82 \%$ ext.), $100 \% \mathrm{WCF}$ and gluten-free flours blends with $2.5 \% \mathrm{PsH}$ or $2.5 \% \mathrm{CMC}$. The results in Table 5 indicated that, all samples of GFBB recorded highest value of weight with significant differences $(p \leq 0.05)$ compared to Balady bread produced from 100\% WF. Balady bread produced from $100 \%$ WCF was very compact and not separated, consequently recorded the lowest scores of volume and specific volume $\left(105 \mathrm{~cm}^{3}\right.$ and $2.75 \mathrm{~cm}^{3} / \mathrm{g}$ respectively).. The samples produced from $100 \%$ WF and GFBB samples (A, B, C, D, E and J). No significant differences in specific volume between them.

However, the GFBB samples containing $2.5 \%$ PsH significantly recorded the highest values of bread volume ranged between $295 \mathrm{~cm}^{3}$ to $315 \mathrm{~cm}^{3}$ in contrast $170 \mathrm{~cm}^{3}$ which investigated by the GFBB samples containing $2.5 \%$ CMC. Consequently the specific volume of GFBB samples containing PsH were higher than others containing $\mathrm{CMC}$ where, no significant differences between the Balady bread produced from $100 \%$ WF ( $82 \%$ ext.) and all GFBB samples containing $2.5 \%$ PsH. Meanwhile, all GFBB samples containing CMC significantly recorded lower values of specific volume compared to the control wheat bread with except the GFBB sample $(\mathrm{J})$ which containing $60 \%$ PS with $2.5 \%$ CMC.

Table 5: Physical properties of wheat Balady bread and gluten-free Balady bread prepared by using different flours blends with $2.5 \%$ psyllium husk or $2.5 \%$ carboxymethyl cellulose.

\begin{tabular}{|c|c|c|c|}
\hline \multirow{2}{*}{ Balady bead samples } & \multicolumn{3}{|c|}{ Quality parameters } \\
\hline & Weight (g) & Volume $\left(\mathrm{cm}^{3}\right)$ & Specific volume $\left(\mathrm{cm}^{3} / \mathrm{g}\right)$ \\
\hline WF (control) & $37.55^{\mathrm{e}}$ & $265^{\mathrm{c}}$ & $7.05^{\mathrm{ab}}$ \\
\hline WCF & $38.40^{\text {de }}$ & $105^{f}$ & $2.75^{\mathrm{f}}$ \\
\hline \multicolumn{4}{|l|}{ GFMF with $2.5 \%$ PsH } \\
\hline $\mathbf{A}$ & $44.25^{\mathrm{ab}}$ & $295^{\mathrm{ab}}$ & $6.70^{\mathrm{b}}$ \\
\hline B & $43.25^{\mathrm{ab}}$ & $320^{\mathrm{a}}$ & $7.40^{\mathrm{ab}}$ \\
\hline $\mathbf{C}$ & $42.60^{\mathrm{b}}$ & $325^{\mathrm{a}}$ & $7.65^{\mathrm{a}}$ \\
\hline D & $43.25^{\mathrm{ab}}$ & $315^{\mathrm{a}}$ & $7.30^{\mathrm{ab}}$ \\
\hline $\mathbf{E}$ & $43.65^{\mathrm{ab}}$ & $315^{\mathrm{a}}$ & $7.25^{\mathrm{ab}}$ \\
\hline \multicolumn{4}{|l|}{ GFMF with $2.5 \%$ CMC } \\
\hline $\mathbf{F}$ & $44.70^{\mathrm{a}}$ & $170^{\mathrm{e}}$ & $3.80^{\mathrm{e}}$ \\
\hline $\mathbf{G}$ & $42.60^{\mathrm{b}}$ & $180^{\text {de }}$ & $4.23^{\mathrm{de}}$ \\
\hline $\mathbf{H}$ & $40.60^{\mathrm{c}}$ & $200^{\mathrm{d}}$ & $4.92^{\mathrm{cd}}$ \\
\hline $\mathbf{I}$ & $39.55^{\mathrm{cd}}$ & $205^{\mathrm{d}}$ & $5.19^{c}$ \\
\hline $\mathbf{J}$ & $39.82^{\mathrm{cd}}$ & $270^{\mathrm{bc}}$ & $6.78^{b}$ \\
\hline
\end{tabular}

Means in the same column with different letters are significantly different $(\mathrm{P}<0.05)$.

$\mathbf{W F}=$ Wheat flour $(82 \%$ ext.).

$\mathbf{W C F}=$ White corn flour.

GFMF $=$ Gluten free mixture flour.

The obtained results are in agreement with Nikouzadeh et al. (2008) they found that the addition of psyllium husk to wheat flour increased the bread moisture content. Also, Czuchajowska et al. (1992) reported similar results. An increase in the absorption of water is caused by the interaction between the hydroxyl groups of water and those of polysaccharide macromolecules present in the husk (Dikeman and Fahey 2006). These results were in a harmony with Mahmoud et al., (2013) they reported that, the gluten-free flat bread formulations based on rice flour, potato starch and corn, blends with addition of hydrocolloids successfully providing stability to the dough mixture during breadmaking and retain the air bubbles in dough. In generally the addition of CMC greatly contributes in the volume increment as reported by Al-Dalain and morsy (2018) which mentioned the addition of hydrocolloids led to improving the gas-cell stability and therefore enhance the specific volume of bread. Also these results are in agreement with Kim et al., (2015) they reported that rice bread containing 20 or $30 \%$ potato starch was rated higher, than that of $100 \%$ rice bread. Also, Yildiz and Dogan, (2014) reported that potato starch can be used to decrease the batter density and hence increasing the volume of bakery products. 


\section{Alkaline water retention capacity of wheat Balady bread and GFBB}

Alkaline water retention capacity (AWRC) consider as a simple and quick test to follow staling of Bread (Nassar et al., 2017). Higher values of AWRC mean higher freshness of Balady bread. The change in freshness characteristics of Balady bread produced by $100 \% \mathrm{WF}$ ( $82 \%$ ext.) and $100 \%$ WCF compared with the samples prepared from different gluten-free mixtures supplemented with $2.5 \% \mathrm{PsH}$ or $2.5 \% \mathrm{CMC}$ were estimated, after the samples stored at room temperature for 0,24 , 48 and $72 \mathrm{hr}$. and the obtained results are shown in Table 6.

Table 6: Alkaline water retention capacity of wheat Balady bread and gluten-free Balady bread prepared by using different gluten free flour blends with $2.5 \% \mathrm{PsH}$ or $2.5 \% \mathrm{CMC}$ during storage for 72 hours at room temperature $\left(25^{\circ} \mathrm{C}\right)$.

\begin{tabular}{ccccc}
\hline \multirow{2}{*}{ Balady bread samples } & \multicolumn{4}{c}{ Storage period (hours) } \\
\cline { 2 - 5 } & Zero time & $\mathbf{2 4}$ & $\mathbf{4 8}$ & $\mathbf{7 2}$ \\
\hline WF (control) & $381.70^{\mathrm{i}}$ & $322.96^{\mathrm{a}}$ & $286.23^{\mathrm{a}}$ & $268.46^{\mathrm{a}}$ \\
WCF & $392.10^{\mathrm{gh}}$ & $273.96^{\mathrm{e}}$ & $241.23^{\mathrm{e}}$ & $197.73^{\mathrm{g}}$ \\
\hline GFMF with 2.5\% PsH & & & & \\
$\mathbf{A}$ & $415.86^{\mathrm{e}}$ & $304.90^{\mathrm{bc}}$ & $256.30^{\mathrm{b}}$ & $217.36^{\mathrm{d}}$ \\
$\mathbf{B}$ & $429.90^{\mathrm{d}}$ & $299.50^{\mathrm{c}}$ & $254.66^{\mathrm{bc}}$ & $223.53^{\mathrm{b}}$ \\
$\mathbf{C}$ & $437.86^{\mathrm{c}}$ & $287.63^{\mathrm{d}}$ & $248.76^{\mathrm{d}}$ & $218.96^{\mathrm{bc}}$ \\
$\mathbf{D}$ & $448.43^{\mathrm{b}}$ & $299.30^{\mathrm{c}}$ & $249.96^{\mathrm{cd}}$ & $223.63^{\mathrm{b}}$ \\
E & $457.26^{\mathrm{a}}$ & $297.83^{\mathrm{c}}$ & $256.16^{\mathrm{b}}$ & $222.50^{\mathrm{bc}}$ \\
\hline FFMF with 2.5\% CMC & & & & \\
F & $388.93^{\mathrm{h}}$ & $309.16^{\mathrm{b}}$ & $241.23^{\mathrm{e}}$ & $217.96^{\mathrm{cd}}$ \\
$\mathbf{H}$ & $397.36^{\mathrm{fg}}$ & $283.13^{\mathrm{d}}$ & $233.70^{\mathrm{f}}$ & $206.96^{\mathrm{e}}$ \\
I & $402.60^{\mathrm{f}}$ & $270.0^{\mathrm{e}}$ & $230.20^{\mathrm{fg}}$ & $206.70^{\mathrm{e}}$ \\
$\mathbf{J}$ & $410.83^{\mathrm{e}}$ & $273.86^{\mathrm{e}}$ & $227.23^{\mathrm{gh}}$ & $200.66^{\mathrm{fg}}$ \\
\hline
\end{tabular}

Means in the same column with different letters are significantly different $(\mathrm{P}<0.05)$.

$\mathbf{W F}=$ Wheat flour $(82 \%$ ext. $)$.

$\mathbf{W C F}=$ White corn flour.

$\mathbf{G F M F}=$ Gluten free mixture flour.

As shown in Table 6. It could be observed that, the sample produced from $100 \% \mathrm{WF}$ significantly recorded the lowest value of AWRC during the first period (zero time) (381.70) followed by 392.10 which recorded by the sample produced from $100 \% \mathrm{WCF}$, whereas the sample produced from $100 \% \mathrm{WF}$ significantly recorded the highest values of AWRC after 24,48 and $72 \mathrm{hrs}$. On the other hand, the gluten-free samples (containing $2.5 \% \mathrm{PsH}$ ) characterized by retention a large amount of alkaline water compared to others containing $2.5 \% \mathrm{CMC}$, however, all GFBB samples whether it contains PsH or CMC were significantly increased as the increment of potato starch in terms of AWRC during all storage periods, and this confirmed with Aprodu and Banu (2015) they studied the effect of dietary fiber (psyllium husk) on gluten free formulation and reported that, dough cohesion was improved by addition of dietary fiber as a result of the hydration properties of fibers. Gluten-free formulation and reported that, gluten-free flat breads containing potato starch, corn flour and hydrocolloids had higher water retention after $72 \mathrm{~h}$ of storage at room temperature in comparison with the control bread (100\% wheat flour) Mahmoud et al., (2013). On the other hand, AWRC values were increased with the increment of the percentages of damaged starch in used mixtures (Barrera et al., 2007).

\section{Sensory evaluation of wheat Balady bread and gluten free Balady bread}

The results in Table 7 stated that, according to the statistical analysis no significant differences between the sample produced from $100 \% \mathrm{WF}(82 \%$ ext.) and the gluten free samples containing $2.5 \%$ $\mathrm{PsH}$ in terms of crust color, separation of layers, roundness, texture, distribution of crumb and odor. However, the increasing of PS in the GFBB samples containing PsH led to improve the degree of crumb color where the dark color of the Balady bread sample prepared from $100 \% \mathrm{WF}$ ( $82 \%$ ext) probably due to the high bran content which gives undesirable color as reported by Bahlol et al., (2012). Also, Pătraşcu et al., (2017) reported the quality of the gluten-free flour with addition of soy 
protein resulted in lighter crumb color and increased texture attributes of resulted bread. However, the increasing of PS in the GFBB samples containing PsH led to decrease taste, mouth feel and overall acceptability degrees and according to the statistical analysis the best sample of GFBB containing $2.5 \% \mathrm{PsH}$ it is consist from $30 \% \mathrm{WCF}+30 \% \mathrm{RF}+30 \% \mathrm{PS}+10 \%$ SPI (sample C). regards the sensory test of GFBB samples containing CMC the results referred to all samples containing CMC were lower in terms of all sensory characteristics compared to the sample produced from $100 \% \mathrm{WF}$ ( $82 \%$ ext.) however all sensory properties of GFBB samples containing CMC were gradually improved with the increasing level of PS. In generally the addition of hydrocolliods led to improve the cohesion of starch granules to produce the desired loaf structure and texture (Al-Dalain and Morsy 2018). As well, the psyllium husk is a promising and novel material for significantly enhance the sensory acceptability of fresh composite Balady bread. Also, Felisberto et al., (2015) reported that the incorporation of protein isolates and fiber in gluten-free bread making is beneficial as it can contribute to improve the structural properties.

Table 7: Sensory characteristics of wheat Balady bread and gluten-free Balady bread prepared by using different blends with $2.5 \%$ psyllium husk.

\begin{tabular}{|c|c|c|c|c|c|c|c|c|c|c|}
\hline \multirow{2}{*}{ Samples } & \multicolumn{10}{|c|}{ Sensory characteristics } \\
\hline & $\mathrm{CC}$ & SL & $\mathbf{R}$ & Tex & Cr.C & DC & $\mathbf{T}$ & Od & MF & OAA \\
\hline Control & $8.6^{\mathrm{a}}$ & $8.6^{\mathrm{a}}$ & $8.7^{\mathrm{a}}$ & $8.7^{\mathrm{a}}$ & $8.0^{\mathrm{bc}}$ & $8.4^{\mathrm{a}}$ & $8.7^{\mathrm{a}}$ & $8.7^{\mathrm{a}}$ & $8.9^{\mathrm{a}}$ & $8.8^{\mathrm{a}}$ \\
\hline \multicolumn{11}{|c|}{ Gluten free bread with $2.5 \% \mathrm{PsH}$} \\
\hline $\mathbf{A}$ & $8.7^{\mathrm{a}}$ & $8.4^{\mathrm{a}}$ & $8.6^{\mathrm{a}}$ & $8.6^{\mathrm{a}}$ & $8.9^{\mathrm{ab}}$ & $8.1^{\mathrm{a}}$ & $8.1^{\mathrm{ab}}$ & $8.2^{\mathrm{a}}$ & $7.9^{\mathrm{b}}$ & $8.3^{\mathrm{ab}}$ \\
\hline B & $8.7^{\mathrm{a}}$ & $8.6^{\mathrm{a}}$ & $8.7^{\mathrm{a}}$ & $8.8^{\mathrm{a}}$ & $9.0^{\mathrm{ab}}$ & $8.2^{\mathrm{a}}$ & $8.3^{\mathrm{ab}}$ & $8.2^{\mathrm{a}}$ & $8.0^{\mathrm{ab}}$ & $8.5^{\mathrm{ab}}$ \\
\hline C & $8.9^{\mathrm{a}}$ & $8.7^{\mathrm{a}}$ & $8.7^{\mathrm{a}}$ & $9.0^{\mathrm{a}}$ & $9.1^{\mathrm{a}}$ & $8.4^{\mathrm{a}}$ & $8.3^{\mathrm{ab}}$ & $8.3^{\mathrm{a}}$ & $8.3^{\mathrm{ab}}$ & $8.7^{\mathrm{ab}}$ \\
\hline D & $8.2^{\mathrm{a}}$ & $8.4^{\mathrm{a}}$ & $8.3^{\mathrm{a}}$ & $8.3^{\mathrm{a}}$ & $9.3^{\mathrm{a}}$ & $8.0^{\mathrm{a}}$ & $7.8^{\mathrm{b}}$ & $8.3^{\mathrm{a}}$ & $8.1^{\mathrm{ab}}$ & $8.3^{\mathrm{ab}}$ \\
\hline $\mathbf{E}$ & $8.1^{\mathrm{a}}$ & $8.3^{\mathrm{a}}$ & $8.2^{\mathrm{a}}$ & $8.3^{\mathrm{a}}$ & $9.3^{\mathrm{a}}$ & $8.0^{\mathrm{a}}$ & $7.6^{\mathrm{b}}$ & $8.0^{\mathrm{a}}$ & $7.9^{\mathrm{b}}$ & $8.0^{\mathrm{b}}$ \\
\hline \multicolumn{11}{|c|}{ Gluten free bread with $2.5 \%$ CMC } \\
\hline $\mathbf{F}$ & $4.9^{c}$ & $3.9^{\mathrm{d}}$ & $5.3^{\mathrm{c}}$ & $4.4^{\mathrm{d}}$ & $5.9^{\mathrm{e}}$ & $4.2^{\mathrm{d}}$ & $3.7^{\mathrm{f}}$ & $5.3^{\mathrm{c}}$ & $4.0^{\mathrm{f}}$ & $3.8^{\mathrm{f}}$ \\
\hline G & $6.3^{b}$ & $5.2^{\mathrm{c}}$ & $6.0^{\mathrm{bc}}$ & $5.0^{\mathrm{cd}}$ & $6.7^{\mathrm{de}}$ & $4.7^{\mathrm{cd}}$ & $4.5^{\mathrm{e}}$ & $5.8^{\mathrm{bc}}$ & $4.5^{\mathrm{ef}}$ & $4.6^{\mathrm{e}}$ \\
\hline $\mathbf{H}$ & $6.5^{\mathrm{b}}$ & $5.6^{\mathrm{c}}$ & $6.2^{\mathrm{bc}}$ & $5.4^{\mathrm{c}}$ & $6.8^{\mathrm{de}}$ & $5.1^{\mathrm{c}}$ & $5.3^{\mathrm{d}}$ & $5.9^{\mathrm{bc}}$ & $5.1^{\mathrm{de}}$ & $5.4^{\mathrm{d}}$ \\
\hline I & $6.6^{\mathrm{b}}$ & $5.7^{\mathrm{c}}$ & $6.3^{\mathrm{bc}}$ & $5.7^{b c}$ & $6.9^{\mathrm{cd}}$ & $5.3^{\mathrm{c}}$ & $5.7^{\mathrm{d}}$ & $6.4^{\mathrm{b}}$ & $5.6^{\mathrm{cd}}$ & $5.9^{\mathrm{d}}$ \\
\hline $\mathbf{J}$ & $7.0^{\mathrm{b}}$ & $6.9^{\mathrm{b}}$ & $7.0^{\mathrm{b}}$ & $6.5^{\mathrm{b}}$ & $7.4^{\mathrm{cd}}$ & $6.5^{\mathrm{b}}$ & $6.6^{\mathrm{c}}$ & $6.5^{\mathrm{b}}$ & $6.3^{\mathrm{c}}$ & $6.7^{\mathrm{c}}$ \\
\hline
\end{tabular}

Means in the same column with different letters are significantly different $(\mathrm{P}<0.05)$.

$\mathbf{C C}=$ Crust color, $\mathbf{S L}=$ Separation of layers, $\mathbf{R}=$ Roundness, $\mathbf{T e x} .=$ Texture, $\mathbf{C r} . \mathbf{C}=$ Crumb color, $\mathbf{D C}=$ Distribution of crumb, $\mathbf{T}=$, taste, $\mathbf{O d}=$ Odor, $\mathbf{M F}=$ Mouth feel and $\mathbf{O A A}=$ Overall acceptability.

Control $=100 \%$ Wheat flour $(82 \%$ ext. $)$.

\section{Conclusion}

The results of the current study show effect of psyllium husk and CMC as binding agents on the quality of GFBB formulations based on white corn flour, rice flour, and potato starch blends with $10 \%$ SPI and the results approved the positive effect of PsH for quality characteristics of resulted Balady bread where the all GFBB samples contained 2.5\% PsH recorded higher values of specific volume with no significant difference compared to the WF Balady bread, and with regard to the GFBB samples which contained 2.5\% CMC significantly recorded lower values of specific volume compared to the WF Balady bread and the same parameter was gradually increased with the increasing level of potato starch where no significant difference between the GFBB sample contained $60 \%$ with $2.5 \%$ CMC and the sample produced from $100 \% \mathrm{WF}$. Concerning the staling of all GFBB samples contained PsH or CMC significantly recorded lower values of AWRC after 24, 48 and $72 \mathrm{hrs}$. compared to the sample produced from $100 \%$ WF ( $82 \%$ ext.). Also, no significant differences between the GFBB samples which containing PsH and WF in terms of overall acceptability for sensory test while the GFBB samples containing CMC significantly recorded lower values of overall acceptability.

\section{References}

AACC, 2000. Approved Methods of the American Association of Cereal Chemists, $10^{\text {th }}$ ed., American Association of Cereal Chemists, St. Paul, Minnesota, USA. 
Abdelghafor, R.F., A.I. Mustafa, A.M. Ibrahim, and P.G. Krishnan 2011. Quality of bread from composite flour of sorghum and hard white winter wheat. Advance Journal of Food Science and Technology, 3(1): 9-15.

Al-Dalain, S.Y., and M.K. Morsy, 2018. Effect of pollutant and hydrocolloids on rheological properties and quality parameters of wheat-soy Balady bread. Food and Nutrition, 9: 32-45.

Amir, B., G. Mueen-ud-din, M. Abrar, S. Mahmood, M. Nadeem and A. Mehmood, 2015. Chemical composition, rheological properties and cookies making ability of composite flours from maize, sorghum and wheat. Journal of Agroalimentary Processes and Technologies, 21(1): 28-35.

AOAC, 2000. Official Methods of Analysis, $17^{\text {th }}$ Ed., Association of Official Analytical Chemists International Gaithersburg, Maryland, USA.

Aprodu, I. and I. Banu, 2015. Influence of dietary fiber, water, and glucose oxidase on rheological and baking properties of maize based gluten-free bread. Food science and Biotechnology, 24(4): 1301-1307.

Aprodu, I., E.A. Badiu and I. Banu, 2016. Influence of protein and water addition on gluten-free dough properties and bread quality. International Journal of Food Engineering, 12(4): 355 363.

Bahlol, H.E., S.A. Soliman, M.H.M. Mahmoud, B.A. El-Latif, and A.H. El-Azm 2012. Production of Balady bread by using some improvers. Moshtohor and Hurghada, 15(24): 18-22.

Barrera, G.N., G.T. Pérez, P.D. Ribotta, and A.E. León, 2007. Influence of damaged starch on cookie and bread-making quality. European Food Research and Technology, 225(1), 1-7.

Boyacioglu, M.H. and B.I. D’Appolonia, 1994. Characterization and utilization of durum wheat for breadmaking study of flour blends and various additives. J. Cereal chemistry, 71(1), 28-34.

Conte, P., C. Fadda, N. Drabinska and U. Krupa-Kozak, 2019. Technological and nutritional challenges, and novelty in gluten-free breadmaking: A review. Polish Journal of Food and Nutrition Sciences, 69(1): 5-21.

Czuchajowska, Z., B. Paszczynska, and Y. Pomeranz, 1992. Functional properties of psyllium in wheat-based products. Cereal Chemistry, 69: 516-520.

Dikeman, C.L. and G.C. Fahey, 2006. Viscosity as related to dietary fiber: a review. Critical Reviews in Food Science and Nutrition, 46: 649-663.

Dizlek, H. and M.S. Ozer, 2016. The Impacts of various ratios of different hydrocolloids and surfactants on quality characteristics of corn starch based gluten-free bread. Cereal Research Communications, 44(2): 298-308.

Eke-Ejiofor, J. and F. Owuno, 2014. The functional properties of starches, physico-chemical and sensory properties of salad cream from cassava and potatoes. International Journal of Nutrition and Food Sciences, 3(6): 567-571.

Faridi, H.A. and G.L. Rubenthaler, 1984. Effect of baking time and temperature on bread quality, starch gelatinization and staling of Balady bread. Cereal Chem., 61(2), 151-154.

Felisberto, M.H.F., A.L. Wahanik, C.R. Gomez-Ruffi, M.T.P.S. Clerici and Y.K. Chang, 2015. Use of chia (Salvia hispanica L.) mucilage gel to reduce fat in pound cakes. LWT-Food Science and Technology, 63: 1049-1055.

Heitmann, M., E. Zannini and E.K. Arendt, 2015. Impact of different beer yeasts on wheat dough and bread quality parameters. Journal of Cereal Science, 63: 49-56.

Hunter, R.S., 1958. Photoelectric color difference meter. J. Optical Soc. of America, 48(12), 985-995.

Kent, N.L. and A.D. Evers, 1994. Bread made with gluten substitutes. Technology of Cereals (pp. 215). Oxford: Pergamon Press.

Kim, M., Y. Yun and Y. Jeong, 2015. Effects of corn, potato, and tapioca starches on the quality of gluten-free rice bread. Food Science and Biotechnology, 24(3): 913-919.

Kitterman, S. and G.L. Rubanthaler, 1971. Assessing the quality of orally generation wheat selection with the micro AWRC test. Cereal Sci., Today, 16: 313-316.

Kohajdová, Z. and J. Karovičová, 2009. Application of hydrocolloids as baking improvers. Chemical Papers, 63(1): 26-38.

Kömen, G., 2010. Structural changes of gliadins during sourdough fermentation as a promising approach to gluten-free diet. M.Sc. Thesis. Graduate School of Engineering and Sciences of İzmir Institute of Technology, Food Engineering. 
Mahmoud, R.M., E.I. Yousif, M.G.E. Gadallah, and A.R. Alawneh, 2013. Formulations and quality characterization of gluten-free Egyptian Balady flat bread. Annals of Agricultural Sciences, 58(1):19-25.

Marco, C., and C.M. Rosell, 2008a. Bread making performance of protein enriched, gluten-free breads. European Food Research and Technology, 227(4): 1205-1213.

Marco, C. and C.M. Rosell, 2008b. Functional and rheological properties of protein enriched glutenfree composite flours. Journal of Food Engineering, 88(1): 94-103.

Mariotti, M., M.Lucisano, M.A. Pagani and P.K.W. Ng, 2009. The role of corn starch, amaranth flour, pea isolate, and Psyllium flour on the rheological properties and ultrastructure of gluten-free doughs. Food Research International, 42: 963-975.

Mousa, E.I., R.H. Ibrahim, W.C. Shuey and R.D. Maneval, 1979. Influence of wheat classes, flour extraction, and baking methods on Egyptian Balady bread. Cereal Chem., 56(6): 563-566.

Nassar, N.R.A., Y.A. Heikal, I.E. Ramadan, M.A.M. Abou-Donia and G.N. Abdel-Rahman, 2017. Characteristics of pan bread and Balady bread produced from different Saccharomyces Cerevisiae strains. Egypt. J. Food Sci. 45: 29-41.

Nikouzadeh, H., A. Taslimy and M.H. Azizi, 2008. Effects of the addition of psyllium husk on the rheological characteristics of dough and quality of sangak bread. In: Proceedings $18^{\text {th }}$ National Congress on Food Technol. Mashhad. Iran [in Persian].

Pătraşcu, L., I. Banu, I. Vasilean and I. Aprodu, 2017. Effect of gluten, egg and soy proteins on the rheological and thermo-mechanical properties of wholegrain rice flour. Food Science and Technology International, 23(2): 142-155.

Raymundo, A., P. Fradinho and M.C. Nunes, 2014. Effect of psyllium fiber content on the textural and rheological characteristics of biscuit and biscuit dough. Bioactive Carbohydrate and Dietary Fiber, 3: 96-105.

SPSS. 2000. Statistical Package for Social Sciences. SPSS for Winds Version 19, SPSS Inc., Chicago, IL, USA.

Waller, R.A. and D.B. Duncan, 1969. A bays rule for symmetric multiple comparison problems. J. of the American Statistical Association, 67, 253.

Yamazaki, W.T. 1954. Interrelations among bread dough absorption, cookie diameter, protein content, and alkaline water retention capacity of soft winter wheat flours. Cereal Chemistry, 31(2): 135-142.

Yildiz, O. and I.S. Dogan, 2014. Optimization of gluten-free cake prepared from chestnut flour and transglutaminase: response surface methodology approach. International Journal of Food Engineering, 10: 737-746. 